Kohl: a Journal for Body and Gender Research

Vol. 6, No. 1 (Summer 2020)

\title{
Beyond Religious Marriages: Civil Marriage, Civil Family Laws, and the Enhancement of Women's Rights in Lebanon
}

Cecile Khoury

\begin{abstract}
:
The present text explores the current confessional system in Lebanon and the possibility of a radical change to a secular state that governs personal status codes under civil laws. In order to do that, it draws on the Tunisian experience with which it shares a common colonial, geographic, and religious experience. I also delve into the possible effects that this reform can have on women's rights in Lebanon while analyzing how the current laws fuel the sectarian system and examine the obstacles of secular change in a sectarian country.
\end{abstract}




\section{Historical context}

After the Lebanese civil war of 1975-1990, the Lebanese parliament signed a National Reconciliation Accord that ended the 15 year long armed conflict. This reconciliation accord is also known as the Taif agreement. It was mainly "the basis for the ending of the civil war and the return to political normalcy [the return to a confessional system] in Lebanon" (Krayem, 1997). What the Taif essentially changed is the ratio of ChristiansMuslims and not the nature of the ongoing political system (sectarian-secular). The Christians to Muslims ratio became 50-50 after the agreement, as opposed to 6-to-5 prior to it.

Following the Taif, the number of ministers in the Lebanese parliament increased from 99 to 126 . In addition, the power was decentralized from the Maronite party through the alteration of the article 17 of the amended constitution. This alteration limited the Maronite president's power. The article was changed into the following: "Executive power shall be entrusted to the Council of Ministers, and the Council shall exercise it in accordance with conditions laid down in this constitution," instead of the previous article that stated: "Executive power shall be entrusted to the President of the Republic who shall exercise it assisted by the Ministers in accordance with conditions laid down in this constitution" (Krayem, 1997). The end goal of the accord was to help Lebanon transition from a point of sectarian tension and move to a point where it becomes a secular country. Although this goal was supposed to be met five years after the ratification of the Taif, it still has not been achieved until today. Lebanon is a country that houses 18 sects. The five major sects in Lebanon are demographically divided as follows: 27 percent of the population are Sunni Muslim, 27 percent are Shia Muslim, 21 percent are Maronite Christian, 8 percent are Greek Orthodox, and 5 percent are Druze (Bureau of Democracy, Human Rights and Labor). However, these statistics can be prone to flaws in them for they are based on 2011's electoral list. Other existing sects include other Christians denominations, smaller groups of Jews, Hindus... Almost all of the 18 sects get "fair" representation in the parliament, following the principle that the number of ministers a sect gets in the parliament is directly proportional to the number of the citizens of the given sect demographically. However, by reinforcing this "fair representation," the government is only drifting further away from the end goal of the Taif, that is the secularization of Lebanon. Another obstacle that withholds the transition to a post-Taif era is the argument that the Taif insures the civil peace in Lebanon, or what is known as Al Silm Al Ahli (الأهلي السلم) in Arabic. It is largely recurrent for current politicians and religious groups to advocate the Taif agreement as a guardian of peace and stability. Furthermore, part of having such a religious diversity yielded to the constitution is providing protection of the religious freedom. In its $9^{\text {th }}$ article, the constitutional law states that "the freedom of belief is absolute and the State shall respect all religions and denominations, ensure free exercise of religious rites, and respect religious interests and personal status laws" (Saliba, 2010). Subsequently, through this article, the Lebanese government sets a great milestone to be overcome in the search of secularization of the country.

Having given this historical background on the Lebanese political scene, I will now discuss marriages and personal status codes in the current confessional system of Lebanon. I will also be comparing it to what it possibly could be in a secular state and discussing the enhancement of women's rights that could underlie this post-Taif secular era. The milestone of the sectarianizing of marriages and personal status laws presents as follows. There are currently 15 different personal status laws in Lebanon that pertain mainly to the 
Christian, the Muslims, the Druze, and the Jewish confessions (Human Rights Watch, 2015). By mapping every person's personal status issues to their religion of birth, these laws create inequalities in access to rights for people from different religious backgrounds. These inequalities create indefinite gaps between people when it comes to attaining marriage, inheritance, divorce, custody, etc., and become a representation of degrees of privilege per religion to attain what must be homogenized civil rights in a civil society.

The situation in Tunisia is quite different. After its independence in 1956, Tunisia drafted its first family law codes. The code was first enforced by Habib Bourguiba, Tunisia's first president whose discourse, as we will discuss later on, focused on the equality between men and women for political reasons. Nevertheless, on a legal level, this focus on equality had prominent effects on policy-making. However, the efforts to implement this reform should not be exclusively attributed to state feminism, or Bourguiba himself. It came to fruition as a result of collective effort, demanded by women activists the likes of Bchira Ben Mrad, Radhia Haddad, and Manoubia Ouertani (Arfaoui, 2007). In addition, credit should be attributed to Tahar Haddad, an academic who predated these reforms in his book "Our Women in Law and Society." This book was largely opposed by conservatives, but it served as the base of a big part of the civil reforms that followed (Moghadam, 2018). What is notable about this scholar is that he embraced the culture of his country, while simultaneously addressing civil right issues and equality through Islam, as for him they were not dissociated (Churchill, 2013). Although the reinforcement of this code was in a top down manner, it still held within it an egalitarian representation of a civil personal status law at the time. Despite the problematics, the code was considered feminist at that time because the only ideology that preceded it was a separate sphere ideology: women belong at home, men in the work field; women compliment men. Of course, the law did no stay static over time. It was modified in 1993 while the successor of Bourguiba, Zine El Abidine Bin Ali was serving as president. These modifications, however, came from feminist activists and the civil society and not directly from the source of the power, which rendered this code a better, although not necessarily ideal, representation of Tunisian women's demands and needs (Code du Statut Personnel, 2012). The reform tackled within it alterations of traditional religious practices that are considered oppressive to women, such as polygamy, age of marriage, right to divorce, right to custody... It is worth noting that the legal documents and their applications do not necessarily indicate a general consensus on these reforms, or even a safe space for women to make use of them or further their cause. But some of the reforms that followed the ratification of the personal status code came out of the efforts of feminist activist groups such as I'Association Tunisienne des Femmes Démocrates (ATFD) and l'Association des Femmes Tunisiennes pour la Recherche sur le Développement (AFTURD), among others. In 1990, for example, women were not to be obedient to their husbands anymore but to be treated with concern. They got the right to handle family affairs (children's affairs, travel, financial affairs). Then again in 2004, women were able to give their name to their child if the father is unknown (Churchill, 2013). Finally, in 2018, women obtained the right to equal inheritance (Sadek, 2018).

As is noticeable, the approach to reach a civil personal status code was completely different between Lebanon and Tunisia, although relatively as two Arabic-speaking countries, they are likely to have a shared experience due to commonalities in their respective histories, and the loose resemblance and exchange between their various cultures and societies. I argue that the aspect that played a huge role in the ratification 
of the civil personal status code is the method adopted by each country to make the shift. Tunisia adopted a radical change. Directly after independence, the code was drafted and ratified within 6 months. Meanwhile, in post-civil war Lebanon, a certain transitional state was supposed to happen, and it was to be governed by the Taif, but, as I explained earlier, the shift never really happened because of the benefits that the religious jurisdiction over personal status codes yields for the parliament. Therefore, it is of evidence that systematic change in a highly religious country is not an effective choice. When we speak of a systematic change, we mean a change that aims to tackle every single policy as an entity of its own, as in, inheritance as a standalone cause, custody as another... and so on so forth. It only allows the habituation to a confessional system instead of preparing the citizens to transition to a civil system. A radical change - meaning, putting all the below mentioned causes under the same umbrella of personal status code and dismantling them - of the system must be done, followed by a process of change and learning and tweaking of the code. My focus falls mainly on the personal status code because I believe it to be a ground for the establishment of equality between women and men that extends beyond its mere drafting or application. Personal status codes have a domino effect on criminal and constitutional codes. They construct the basis of law that aims to protect from violence and injustices such as child marriage and sexual harassment, and explain phenomena such as the lack of representation of women in the political sphere.

\section{Civil Marriages in Lebanon}

To say that civil reform in Lebanon was not sought after is erroneous. On the contrary, although civil marriage is not legal in Lebanon, it has always been a topic of debate. In fact, the first time civil marriage was discussed in the parliament was in the 1950s when religious courts, notably Christian courts, got the total power to govern family laws. Both Christians and Muslims were very much in favor of the 1951 law. However, they faced great opposition from members of the syndicate of lawyers who were secular and who threatened to go on a strike. As of that point, conversation surrounding the topic of civil marriages started to surface. Subsequently, in 1971, the first civil personal status law was submitted to the parliament, only to be rejected due to sectarian tensions that were rising because of the parliamentary positions (Christians-Muslims ratio). ${ }^{1}$ What intensified the religious tension at that time was the spark of the civil war in 1975, and later trials of legalizing civil marriage were met with backlash from religious figures due to the ongoing tension. After this major shift in power dynamic, the civil society tried to lobby multiple times in that time frame for the legalization of civil marriage, yet they were met with rejection (Dabbous, 2017). Then again, in 1998, president Elias El Hrawi submitted a bill to the parliament that, alongside other personal status laws, included the introduction of civil marriage in Lebanon (Zuhur, 2002). Twenty-two ministers at the time signed in favor of this bill. However, the Prime Minister Rafiq Hariri refused to sign it, claiming it needed further reconsiderations in some parts regarding personal status laws. In addition to that, some of the religious parties' leaders were infuriated by the bill, and claimed that it was a threat to the morals and the values of religion and to religious freedom itself. This resistance came majorly from the Sunnis and the Maronites, whose leaders took it upon

\footnotetext{
1 There is no clear documentation of the proposed law of 1971, nor of the party that proposed it. Matter of fact, there is no concrete documentation of most of the proposed civil marriage laws in Lebanon.
} 
themselves to make it clear that the bill should not be an option in the first place (Ofeish, 1999). Another draft of a law on civil marriage was presented to the parliament in 2011 , drafted by a number of NGOs and secular organizations, but the draft did not even get the chance to be debated, due to immediate rejection (Abou Jaoude, 2014). More recently, minister Raya El Hassan, who is the past minister of interior and municipality, revived the debate on civil marriage by declaring her intention to tackle it (Naharnet Newsdesk, 2019). However, these intentions never really manifested into action, as the country is still operating under the same political machine that existed post-civil war, with Raya El Hassan being part of that system. The opposition to the past government(s) was made vocal through the revolution that started on October $17^{\text {th }} 2019$, and that was initially ignited following additional taxes that the government was trying to implement. However, the taxes were only the tip of the iceberg; there were other underlying causes as to why people took the streets, some of which include the living conditions, inflation, the economic crisis... Some of the protesters found this revolution to be an opportunity to ask for the transition from a sectarian to a secular state.

As seen above, although religious marriages and religious personal status laws are common in Lebanon due to their availability, some Lebanese citizens still insist on getting a civil marriage. Being omitted from legal texts in Lebanon, some citizens seeking civil unions travel to neighboring countries such as Cyprus and Greece to get it. In fact, the Ministry of Foreign and Expatriate Affairs in Lebanon announced that 560 Lebanese couples travelled to Cyprus and got a civil marriage in 2014 (Hamadi, 2018). Couples married abroad would then come back to Lebanon and register their marriage legally, as the state will recognize their foreign civil marriage. These types of marriages are legal in Lebanon and the couple follows the personal status law of the country they got married in. So, in any case of divorce, inheritance issues, or custody, the couple refers to the civil laws of the country they got married in to solve their legal affairs. In an exceptional case in 2013, Nidal Darwish and Khouloud Succariyeh managed to get civilly married on Lebanese grounds. This accomplishment was followed by eight other successes of civil marriage on Lebanese soil, which were achieved through a loophole in the law. During the French mandate, the decree no. 60 of 1936 allowed Lebanese people who did not belong to a sect to marry civilly without religious interference. This decree was made back then in order to facilitate the marriage of non-Lebanese, mainly French men to Lebanese women. Thus, since it is legal, the couples mentioned above removed their sects from their Lebanese identification cards and made their case. However, a major setback is that there are no civil personal status laws in Lebanon. Therefore, it is complicated to actually register and recognize these marriages, because they do not have a basis in a clear family law. This point was one of the greatest setbacks, since it requires investigation by the state when it comes to personal status law and the implementation of the constitutional law that states that women and men are equal, thus dismantling the power dynamic that has been perpetrated by religious marriages for years. In the upcoming section, I will discuss the importance and repercussions of the implementation of a personal status code on women's rights in Lebanon. I will be basing my arguments on the law present in the Tunisian personal status code or "الثخصية الأحوال مجلة", for, as mentioned above, it is legally one of the most egalitarian in the MENA region, and because of the shared experiences that Tunisia and Lebanon have as countries that have been colonized by the French and were functioning on sectarian basis before their independence. Ideally, these personal status code reforms would be enforced on all marriages in Lebanon, whether civil or religious. 


\section{On marriage reforms}

One of the first aspects that a personal status code can take into consideration is that of the legal age of marriage. According to the UNDP, "The [Tunisian] Personal Status Code was revised in 2007 to set the legal age of marriage for each spouse at 18 years." The previous article 5 in the 1956 version of the code stated that the marriage could happen if both the girl and the man have attained the age of puberty. However, the age of puberty of girls was considered 15 years of age whereas that of the man was 18 years of age (Sfeir, 1957). When considering civil reforms, this is an important point the Lebanese government would have to focus on. In religious marriages, according to the UNDP:

All religious groups allow girls under the age of 18 to marry. Among Sunni and Shiite Muslims, marriage of girls as young as nine years can occur if approval is granted, although it is no longer customary that such young girls marry. Among the Jewish denomination, girls as young as $12 \frac{1}{2}$ years may marry. Among Syrian Orthodox and Armenian Orthodox churches, a girl may be 14 years old when she marries. The marriage age for boys of most religious groups is 18 , although marriage of younger boys can be approved. (UNDP, 2018)

The legal age for marriage in Lebanon still allows for child marriage to take place. Many Lebanese feminist NGOs such as RDFL (The Lebanese Woman Demographic Gathering) and ABAAD have opposed it through campaigns, protests and conferences (EuroMed Feminist Initiative, 2017; ABAAD \& Arab Institute for Human Right, 2015). In addition to these NGO efforts, many personal initiatives and efforts, absented to a larger extent due to their lack of documentation, were also put into this cause. By keeping child marriage legal, Lebanon is violating the rights of children as drafted in the Convention on the Rights of the Children, of which Lebanon is not only a signatory but also a ratifier. Therefore, as evaluated by the UNICEF, Lebanon would be in violation of articles $9,13,19,24,28,31,34$, and 36 (de Silva de Alwis, 2007). ${ }^{2}$ When we speak of child marriage, we usually speak of underage girls getting married because this is predominantly the case in Lebanon. This is in fact a gendered problem. Girls are being used as sexual objects by older men in order for their families to preserve their family honor, or what is known in Arabic as al sutra. Moreover, some girls are being trafficked into marriage due to their parents' low socio-economic status, which results in their selling their daughters off to get married (ABAAD \& Arab Institute for Human Right, 2015). One additional reason why many girls are being married off at such a young age is speculated to be because parents, most notably refugees, perceive themselves to be protecting their daughters from sexual abuse. However, they are putting

\footnotetext{
2 The article discussed above states the following:

"The right to education (Article 28). The right to be protected from all forms of physical or mental violence, injury or abuse, including sexual abuse (Article 19) and from all forms of sexual exploitation (Article 34). The right to the enjoyment of the highest attainable standard of health (Article 24). The right to educational and vocational information and guidance (Article 28). The right to seek, receive and impart information and ideas (Article 13). The right to rest and leisure, and to participate freely in cultural life (Article 31). The right to not be separated from their parents against their will (Article 9). The right to protection against all forms of exploitation affecting any aspect of the child's welfare (Article 36)."
} 
their daughters under the risk of marital sexual abuse that could go to the extent of rape. According to the Girls Not Brides organization, "6\% of Lebanese girls are married before their 18th birthday and $1 \%$ are married before the age of 15" (Girls Not Brides, 2018). Until child marriage is banned in Lebanon, taking into consideration the minimal legal age for marriage is vital in applying a truly just civil personal status law. It is eminent to say that underage marriage under a civil system should be banned even upon the guardians' approval.

Moreover, as mentioned in article 3 of the Tunisian code, "marriage can only be entered into with the consent of both spouses" (Code du Statut Personnel, 2012). ${ }^{3}$ It is true that in all religions the woman has to consent in order for the marriage to take place. However, there are exceptions to the rule: "this right is automatically annulled when the woman in question is married at birth, at the ages of 9 or even 13 or 15 , or, worse, when she is married by proxy" (Shehadeh, 2010). The majority of forced marriages in Lebanon are child marriages. However, this does not deny the existence of forced marriages at legal ages. Reasons for these marriages may vary. Some may be for the preservation of the family's honor if a woman was seen with a man who is not part of the family. Other forms of forced marriages that are still practiced in Lebanon are arranged marriages, which can take place because the man is wealthy, and the family of the girl is in need of money, so they rely on their daughter's new husband for financial support on the one hand, and rid themselves from the responsibility of having to financially support their daughter on the other. Further research needs to be done on this topic, for the statistics are scarce due to the its sensitivity. Another underlying reason of these forced marriages are sectarian problems. In Lebanon, it is still taboo in conservative households to marry a person from a different sect. Therefore, many families resort to early or forced marriages to resolve this issue, despite it being practiced regardless, even when it comes to people who marry at a later age.

With regards to the marriage contract, in the present 15 laws of personal status, mixed marriages are allowed in the following form:

A Sunni or Shia (Muslim) man can marry a Christian or Jewish woman without her having to convert herself, but a Muslim woman cannot marry a Christian or a Jew. Catholic men can marry a Muslim woman. In this case the couple receives the blessing at the sacristy, and the children must be baptized and raised as Catholics. Druze community only allows inter-Druze wedding...The same apply for the Israelite community. Orthodox church allows weddings with Muslims under the conversion condition. Under Muslim law, polygamy is permitted. (Salah Mattar Law Firm, n.d.)

Thus, allowing women to marry men of other religions would be considered a great step in the direction of equality between women and men, and a step in the direction of dismantling the sectarian system. The privilege of men marrying women of other religions exists in most religions, and the woman is the counterparty that has to go above and beyond to marry a man of a different religion. This right to mixed marriage would facilitate women's marital process. One thing that must be noted from the previous passage is the accessibility for men in Muslim religious marriages to polygamy. In Tunisia, this right is prohibited in the

${ }^{3}$ Revised by Law No. 32, 14 May 2007. 
personal status code and punishable by law. Article 18 of the code states: "Polygamy is prohibited. Marrying more than one woman shall incur a punishment of one year's imprisonment and a fine of 240,000 francs or either of these" (Code du Statut Personnel, 2012). Applying such a reform to the personal status law will set a common ground for both the man and the woman to build the marriage on, without the woman feeling constantly threatened by the option of polygamy, and would contribute to a decrease in psychological violence against women. In addition, it would contribute to a decrease in child trafficking marriages.

A civil code also takes into consideration a type of marriage that applies to the Shi'ite and Sunni sects and that is Zawaj Al Mot'a or "المنعة زواج", which directly translates to "pleasure marriage." With this type of temporary marriage, a man is allowed to temporarily "marry" a woman in order to have sexual intercourse with her and then later on cancel the marriage, with the intercourse being considered halal. Hence, for women who do not necessarily want this practice or approve of such marriage for themselves, the objectification of women's bodies would decrease under that code, and would render what is essentially cheating in monogamous relationships a legitimate reason for women to file for divorce, especially that it is prohibited for married women to engage in this type of marriage, let alone initiate it. While this practice is empowering for some women and give them sexual choices they wouldn't otherwise have after they are widowed or divorced, our focus is on those who would like the option of it being a religious practice rather than a legal one.

\section{Divorce, Custody and Inheritance Reforms}

Divorce laws are highly discriminative against women. This not only lies in the laws themselves but also in the courts of law. In Christian laws, divorce is mostly prohibited. However, in Greek Orthodox sects, divorce may be admissible in case the man deems it so. This means that if a man finds out that his wife is not a virgin upon marriage, he has the right to divorce her. Moreover, if she disobeys him or does not fulfill the rules that the church imposes in marriage, the man has the right to make a case and divorce his wife. Other marital problems are taken into consideration too, but in general it is very hard to get a divorce in the Christian sects especially in the Maronite sect (Shehadeh, 2010). For Muslims, both Shia and Sunni men have the complete right to divorce their wives whenever they deem appropriate, even without her consent or knowledge. However, for Sunni women to be able to file for divorce or to dissolve a marriage without the spouse's approval, the spouse must first share the 'isma with his wife. Although admissible, sharing the "isma with one's wife is highly frowned upon and very rare. Therefore, without 'isma, Sunni women only have one resort: to file for divorce through filing for severance: "Sunni women can only initiate a divorce by filing for severance-dissolution of the marriage by judicial order for reasons specifically enumerated under religious law" (Human Rights Watch, 2015). As for Shia women, severance is not an option as it is not recognized by their confessional law. Therefore, this greatly limits Shia women's ability to file for divorce. A Shia woman can only access divorce through seeking relief from a Ja'fari religious authority. This is known as "sovereign divorce," where women seek this relief outside the court, and then this religious authority may be able to divorce the woman on the behalf of her husband. It is evident that the divorce process for women is far more complex and harder than it is for men. What this means is that religious marriage deprives women of their autonomous nature and her agency, to subsequently manipulate them into staying in marriages that could 
possibly be abusive or failed. Ideally, in this matter too, we can draw on the Tunisian personal status code for an example of a fair divorce law. Article 31 states the following:

A divorce decree is given: (1) In pursuance of an application by the husband or the wife and for the reasons provided for in this code. (2) In pursuance of the mutual consent of both spouses. (3) In pursuance of the husband's desire to divorce or the request of the wife for same, in which case the judge shall determine the financial indemnity to which the wife may be entitled by way of damages or the indemnity which she has to pay to the husband (Code du Statut Personnel, 2012).

Nevertheless, it is also important to recognize that marital abuse is enough of a reason for the women to file for divorce. In our present time and in sectarian confessions, this reason is still not considered enough. Therefore, it is important to mention that within the divorce laws and standards, there should exist a law that protects women from marital partner violence or domestic violence. That law should consider the latter two cases a legitimate reason for a woman to be granted immediate divorce.

As for custody, in all Shia, Sunni, Druze, and Christian confessions, it is the children's age that determines whether they reside with their mother or father. That being said, Human Rights Watch highlights how this fails to live up to the standard put by the Convention on the Rights of the Child. This convention perpetrates the idea that "in all matters concerning children, the best interest of the child shall be a primary consideration" (de Silva de Alwis, 2007).

Alongside custody, religious courts have the concept of guardianship, which is taking care and bringing up the child till the age of 18. However, in both these cases, there is a general tendency towards giving the men the right to custody or guardianship or to his family in case of death and not divorce. In addition, cases of women and custody or guardianship are especially scrutinized. This is especially witnessed when women try to keep the custody after the assigned age of the child or when the husband tries to take the children away from the mother before the assigned age. This phenomenon is so prevalent that for years, multiple groups and individuals have been trying to put pressure on the religious courts to change their policies. One of the most prominent example is that of Nadine Jouni, a feminist activist whose son was taken away from her at a very young age. She then spent the remainder of her life trying to win back his custody and change the laws behind this unjust treatment. These demands regarding custody (even the right of women to pass on their nationality to their children) were prominent in the October 17 revolution. On February 29 2020, around 200 women took the streets and protested outside the Higher Islamic Shiite Council, as a reaction to a video of a mother who was not allowed to approach her daughter's grave, two years after losing custody of her (Megaphone, 2020). This is not a stand-alone story. Women could easily lose their case if they were of a different religion or sect of that of the father, for the authorities' fear that the child's religious inclinations would change. Moreover, if the woman remarries, she has less of a chance to retain custody of her children. These implications are not the same for men who are considered to be raising their children on the morals and rules of the religion or the sect they belong to. In this equation, the new wife is but an addition to provide a "healthy frame" for the child's growth (de Silva de Alwis, 2007). Such laws reinforce the Taif agreement in Lebanon, for it assures that no matter if the man marries a woman from a different sect, the child will follow that of the 
man and keep the demographic balance moving in the direction of the birth determined sect. Same applies to the issue of women not being able to pass on their names to their kids, for it would cause demographic anxieties in the presently ruling political parties and risk a change in the present confessional system.

The Tunisian law on custody, I would argue, still needs reforming before it is considered civil, for in some articles like article 59, we still witness embedded sectarian roots. The child's best interest should be put at the forefront of a divorce, no matter if the mother is of the same or a different sect than the child.

As for inheritance, for the Sunnis, a female heir gets half of what the male heir gets. For instance, if the father of a boy and a girl dies, the daughter gets $1 / 3$ of her father's property while the son gets $2 / 3$. In case the man was in a polygamous marriage, his wives get equal inheritance. In the Ja'fari denomination, inheritance is based on rank. The extended family is divided to 3 classes: $1^{\text {st }}$ class includes the parents and the children, $2^{\text {nd }}$ class includes grandparents, brothers, and sisters, $3^{\text {rd }}$ class includes paternal uncles and aunts, and maternal uncles and aunts followed by their kids. These classes are divided with no account to gender. The person with the higher rank inherits everything, without discrimination based on gender. However, if there are two people of the opposite sex in the same rank, the male gets twice the inheritance of the female. As for the Druze, they follow a Hanafi Islamic School of thought that is very similar to that of the Sunnis. However, in 2017, an amendment to the Druze personal status law was put in effect. This amendment greatly benefits the daughter of the person who is deceased. "If the deceased had only a female child, the girl will be considered in a league by herself, and she will inherit the entire estate. If there are multiple girls, the shares are distributed evenly" (Ofeish, 1999). As for the Christian rules of inheritance, the property or wealth is divided equally between all the family. Thus, if we were to speak about possible equal inheritance rules under civil marriage, we can compare the possible laws to those of Christians or those of Tunisia too. In their personal status code, there is an in-depth elaboration on how to divide the wealth fairly and equally between the article 119 and the article 112 .

\section{Civil Personal Status Codes and Women}

Personal status codes go beyond regulating issues of marriage, divorce, inheritance... They are directly related to issues such as women's autonomy, their reproductive health, and their body. A civil personal status code paves the way for women to obtain the rights they aspire to get through criminal and constitutional laws, for it is more difficult to tackle women's struggles through criminal laws and the constitutional law. It is mentioned in the Lebanese constitutional law that women and men are equal, but when the code that organizes people's personal lives is inherently sexist, it is hard to reflect that image in other areas of women's lives. And when I talk about private lives here, I mean it regulates family lives. In a communal society, family life is no longer something that is exercised in small entities and in the privacy of one's home. It is a public aspect of life. Everyone is involved in each other's familial issues. It is not the nuclear family only, but the extended one. When this essentially private part of one's life is made so available to the gaze of other members of society, it becomes political, especially when it negatively impacts the life of women in Lebanon in different degrees. For example, when a woman by virtue of the personal status code can pass her name 
to her children, then she is setting the grounds to having the right to passing on her nationality. When her name is seen as an entity in itself, her nationality and sect are also seen as part of her identity and not temporary means of identification until marriage. This is one of the main causes why a civil code has not been enforced yet: it directly terrorizes the current system, it threatens demographic change, and, subsequently, political/religious quotas. And so, the issue becomes a tool of preservation of the current political system and its sectarian structure and properties. Furthermore, it gives the woman her own identity; she stops being her father's, husband's, or brother's subordinate and reaches a sort of liberation herself and thereafter acquires the right to exercise her freedom. Another example is how the civil code grants the woman her bodily rights to autonomy. Under a civil code, the woman is under no obligation to sleep with the groom, subsequently this obligation cannot be used as an excuse to justify marital rape. A Catholic man is no longer capable of denying his wife contraception, even though it is now available and free in primary health centers, as it is a health service that should be available to all women upon their demand (Mikdashi, 2014). On a political basis, a woman running for elections is no longer dismissed as she cannot carry the name of her family to the parliament if she were married. And the list goes on.

\section{Conclusion}

To conclude, there are three key concepts in Lebanese politics that go hand in hand: post-Taif, women's right, and civil laws. These three concepts are intertwined. We cannot imagine a post-Taif era without civil reforms, and we cannot think of civil reforms and civil laws without connecting them to women's rights. These reforms should be radical in nature. However, this would require the efforts of a big part of the feminist organizations, groups, and individuals in Lebanon. We have grown accustomed to sectarianism to the extent that it has become engrained not only in our political, but also in our cultural and social life. Thus, dismantling such a structure would need the collective efforts of most, if not all, the feminist groups in Lebanon to create a pressure group alongside the civil reform activists. It is not a simple process, but one that requires strategic planning, extensive conversations and debates to happen between the activists and the people, and perseverance in the pressure applied on the government without falling into the negotiation zone, but only further reaffirming the need for a radical structural reform. Some of the main problem that this transition would face are the lack of archiving of previous proposals to personal status codes proposed (obviously as they serve to avert people's attention to other possibilities that are not rooted in sectarianism), the lack of research on issues related to women in Lebanon, and the lack of resources. Nevertheless, we can benefit from the oral history we have and build on it, for change must come out of the voices and stories of women who are living in systematic oppression every day. With the October revolution, most of the revolutionary groups refused to negotiate, documenting demands instead. Women's voices and feminist groups, prevalent in the streets, stated their demands loud and clear, and were no longer afraid to discuss the history of their oppression. In addition to that, more non-partisan, or non-sectarian media outlets surfaced (such as the October 17 newspapers تشرين 17 جريدة) or gained more traffic (such as Megaphone). The presence of such outlets is vital for the better documentation of events, and further organization of the movement. While there still are groups, and especially NGOs, who will always choose to take the systematic route, the feminist movement in Lebanon is reinventing itself into a radical one, especially through the work of feminist groups 


\section{Kohl 6.1}

87 in the revolution. Its hows and whats are still beyond our imagination, but I believe that radical change is in the making. 


\section{References}

ABAAD \& Arab Institute for Human Right. (2015). Regional Seminar on Child Marriage during democratic transition and armed conflicts. Retrieved from https://www.girlsnotbrides.org/wpcontent/uploads/2016/06/ABAAD-Lebanon-Regional-Seminar-on-Child-Marriage-Report-2015.pdf

Abou Jaoude, R. (2014, January 10). Civil marriage is legal in Lebanon: experts. The Daily Star. Retrieved from https://www.dailystar.com.lb/News/Lebanon-News/2014/Jan-10/243642-civil-marriage-islegal-in-lebanon-experts.ashx

Arfaoui, K. (2007). The Development of the Feminist Movement in Tunisia 1920s-2000s. The International Journal of the Humanities: Annual Review, 4(8), 53-60. doi: 10.18848/14479508/cgp/v04i08/42025

Bureau of Democracy, Human Rights and Labor. (n.d.). International Religious Freedom Report for 2011. Retrieved from https://20092017.state.gov//drl/rls/irf/2011 religiousfreedom/index.htm?dlid=192441\&year=2011\#wrapper

Churchill, E. (2013, March 8). Tahar Haddad: A towering figure for women's rights in Tunisia. World Bank Blogs. Retrieved from https://blogs.worldbank.org/arabvoices/tahar-haddad-towering-figurewomen's-rights-tunisia

Code du Statut Personnel. (2012). Journal Officiel De La République Tunisienne. Retrieved from https://www.lo.org/dyn/natlex/docs/ELECTRONIC/73374/74946/F-1287339442/TUN-73374.pdf

Dabbous, D. (2017). Legal Reform and Women's Rights in Lebanese Personal Status Laws. CMI. Retrieved from https://www.cmi.no/publications/file/6341-legal-reform-and-womens-rights-inlebanese.pdf

de Silva de Alwis, R. (2007). Child Marriage and The Law. UNICEF. Retrieved from https://www.unicef.org/french/files/Child_Marriage_and_the_Law.pdf

EuroMed Feminist Initiative. (2017, October 16). RDFL Launches Its Media Campaign Against Early Marriage. EuroMed Feminist Initiative. Retrieved from http://www.efi-ife.org/rdfl-launches-its-mediacampaign-against-early-marriage

Girls Not Brides. (2018, December 18). Lebanon - Child Marriage Around the World. Girls Not Brides. Retrieved from https://www.girlsnotbrides.org/child-marriage/lebanon/\#stats-references

Hamadi, G. (2018, March 9). Between Religion and State: Civil marriage remains an elusive goal. Beirut Today. Retrieved from https://beirut-today.com/2018/03/09/religion-state-civil-marriage-remainselusive-goall

Human Rights Watch. (2015, January 19). Unequal and Unprotected: Women's Rights under Lebanese Personal Status Laws. Human Rights Watch. Retrieved from https://www.hrw.org/report/2015/01/19/unequal-and-unprotected/womens-rights-under-lebanesepersonal-status-laws

Krayem, H. (1997). The Lebanese civil war and the Taif Agreement. In: Salem, P. (ed), Conflict Resolution in the Arab World: Selected Essays, 411-436. Beirut: American University of Beirut.

Mikdashi, M. (2014). Sex and Sectarianism: The Legal Architecture of Lebanese Citizenship. Comparative Studies of South Asia, Africa and the Middle East, 34(2), 279-293. doi: 10.1215/1089201x2773851 
Moghadam, V. M. (2018). The State and The Women's Movement in Tunisia: Mobilization, Institutionalization, and Inclusion. James A. Baker III Institute for Public Policy. Retrieved from https://www.bakerinstitute.org/media/files/files/e83637ea/cme-pub-carnegie-moghadam092618.pdf

Naharnet Newsdesk. (2019, February 18). Controversy as al-Hassan Revives Debate over Civil Marriage. Naharnet. Retrieved from http://www.naharnet.com/stories/en/256670

Ofeish, S. (1999). Lebanon's Second Republic: Secular Talk, Sectarian Application. Arab Studies Quarterly, 21(1), 97-116. Retrieved from www.jstor.org/stable/41858278

Sadek, G. (2018, December 4). Tunisia: Cabinet Approves Bill Requiring Equal Inheritance Shares for Men and Women. Retrieved from https://www.loc.gov/law/foreign-news/article/tunisia-cabinet-approvesbill-requiring-equal-inheritance-shares-for-men-and-women/

Salah Mattar Law Firm. (n.d.). Marriage Lawyers in Lebanon. Retrieved from http://mattarlaw.com/marriage-in-lebanon/

Saliba, I. (2010). Lebanon: Constitutional Law and the Political Rights of Religious Communities. Retrieved from https://www.loc.gov/law/help/lebanon/contitutional-law.php

Sfeir, G. (1957). The Tunisian Code of Personal Status (Majallat Al-Ahw Al Al-Shakhsiy Ah). Middle East Journal, 11(3), 309-318. Retrieved from www.jstor.org/stable/4322925.

Shehadeh, L. (2010). Gender-Relevant Legal Change in Lebanon. Feminist Formations, 22(3), 210-228. Retrieved from www.jstor.org/stable/40980991

UNDP. (2018). Gender Justice and the Law: Assessment of Laws Affecting Gender Equality in the Arab States Region. Arab States UNDP. Retrieved from https://www.arabstates.undp.org/content/rbas/en/home/library/Dem_Gov/gender-justice-and-thelaw-study.html

Zuhur, S. (2002). Empowering Women or Dislodging Sectarianism?: Civil Marriage in Lebanon. Yale Journal of Law and Feminism, 14(5). Retrieved from https://digitalcommons.law.yale.edu/yjlf/vol14/iss $1 / 5 /$ 